\title{
Non-Traumatic, Spontaneous Extra-Dural Haemorrhage: A Rare Neurosurgical Emergency of Beta-Thalassemia Major
}

Yee Hwa Khoo ${ }^{1 *}$, Lalithambigai Gannison¹, Wei Jin Wong ${ }^{2}$, Mohd Sofan Zenian¹, Chung Ket Lai ${ }^{2}$ and Pulivendhan Sellamuthu ${ }^{1}$

${ }^{1}$ Department of Neurosurgical, Queen Elizabeth Hospital, Malaysia

${ }^{2}$ Department of Surgical, Duchess of Kent Hospital, Malaysia

Submission: June 18, 2019; Published: July 01, 2019

*Corresponding author: Khoo Yee Hwa, Hospital Queen Elizabeth, Karung berkunci no. 2029, 88586, Kota Kinabalu, Malaysia

\begin{abstract}
Intracranial Extradural Hematoma (EDH), a collection of blood between the skull and the dura, is a common sequelae of head trauma Spontaneous EDH without underlying medical causes has been reported in intraspinal lesions but rarely in intracranial conditions. Spontaneous EDH with haematological disorders is rarer still. Previous literatures have reported on cases of spontaneous EDH because of sinus, middle ear, orbital infections, disorders of blood coagulation. We report a case of a spontaneous EDH on a background of Beta Thalassemia Major which has yet to be reported.
\end{abstract}

Keywords: Neurosurgery; Hematoma

Abbreviations: EDH: Intracranial Extradural Hematoma; GCS: Glasgow Coma Scale; CT: Computed Topography; MRI: Magnetic Resonance Imaging;

\section{Introduction}

Intracranial Extradural Hematoma (EDH), a collection of blood between the calvaria and the dura, is a common sequelae of head trauma, and can lead to significant morbidity and mortality if management is delayed [1]. Spontaneous EDH without underlying medical causes has been reported in intraspinal lesions but rarely in intracranial conditions [2,3]. Spontaneous EDH with haematological disorders is rarer still [46]. We report a case of a spontaneous EDH on a background of Beta Thalassemia Major. To the authors' knowledge, this is the first reported case of spontaneous EDH with Beta Thalassemia Major, worldwide.

\section{Case Report}

A transfusion-dependant, 16-year-old female with Beta Thalassemia Major complicated with Iron Overload (diagnosed at the age of 1 year and 4 months with $\mathrm{HbA2} 2.1 \% \mathrm{HbF} 89.5 \%$ ), presented to our casualty on the 31st of December 2018 after she was found unconscious at home by her parents. There was no history of head trauma or infection. Prior to presentation, she had complained of gradually worsening shortness of breath and headache over the course of 5 days. Upon neurological examination, her Glasgow Coma Scale (GCS) was E1V1M1 with unequal, bilaterally sluggish pupils. The right pupil was larger than the left. Vital signs were normal. She was markedly anaemic with a Haemoglobin concentration of $6.9 \mathrm{~g} / \mathrm{dL}$. Coagulation profile results were not available due to technical issues. Other biochemistry parameters were within normal ranges. An urgent non-contrasted Computed Topography (CT) scan of the brain showed a thick bifrontal extradural hematoma of mixed densities with a maximum thickness of $2.3 \mathrm{~cm}$, causing mass effect to the surrounding brain parenchyma (Figure 1), and widening of the frontal and biparietal diploic spaces. (Figure 2) There were no skull fractures. Other history is significant for iron overload cardiomyopathy, proven on a previous Cardiac Magnetic Resonance Imaging (MRI) in 2015. An echocardiogram in the same year showed normal ventricular function. An emergent craniotomy and clot evacuation were done. Intraoperatively, there was no evidence of skull fracture. A thick, well-organised clot was seen bi-frontally. (Figure 3) Osteolytic and hemopoietic changes were seen over the anterior calvarium. (Figure 4) Slow diffuse bleeding was seen over the dura surface and osteolytic bone, which was controlled with bipolar cautery and application of bone wax. 

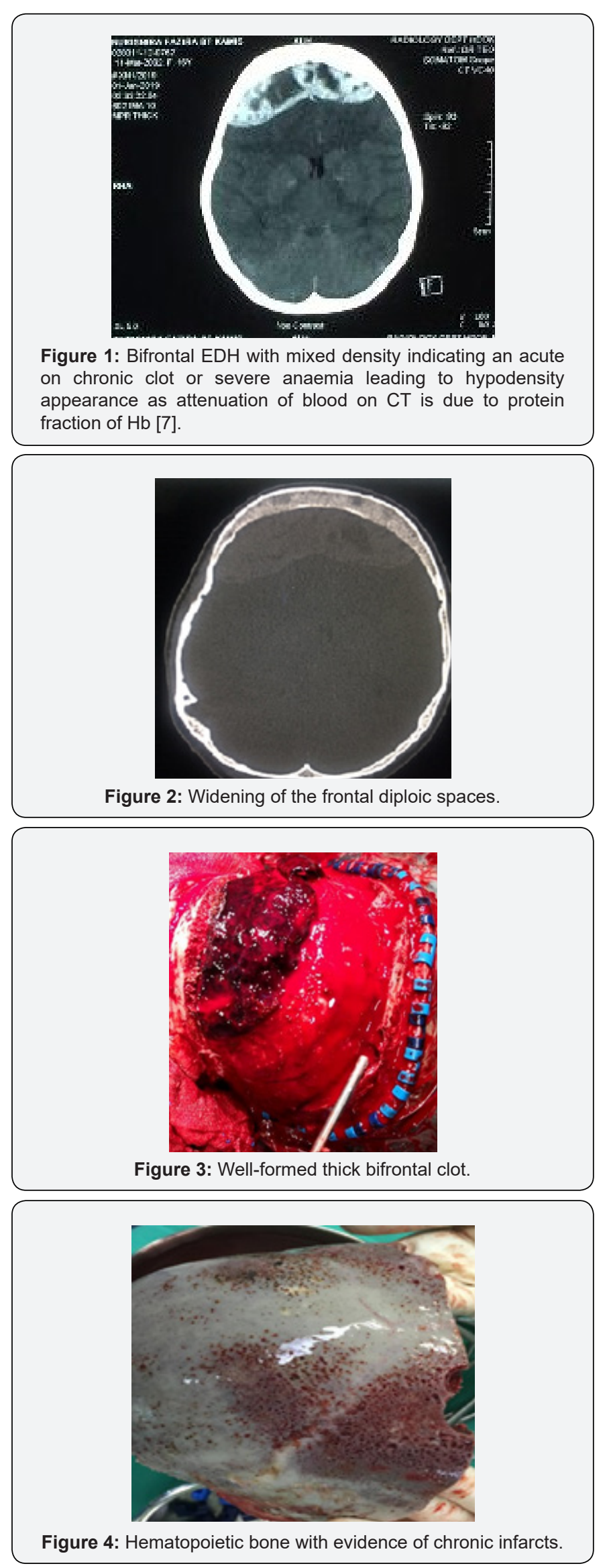

\section{Discussion}

The aetiology of EDH is almost always traumatic [1]. Hematoma results from ruptured middle meningeal vessels or diploic veins, and skull fractures are estimated to be associated in $65-90 \%$ of patients [8]. Reported causes of spontaneous EDH include - vascular malformations of the dura, sinus, middle ear, or orbital infections, hematological disorders such as sickle cell anemia, Systemic Lupus Erythematosus (SLE), tumors, and open-heart surgery $[9,10]$. Spontaneous EDH associated with Thalassemia has never been reported in the literature to date, thus, the mechanism is vague. Hypercoagulability is a wellestablished characteristic of beta thalassemia, due to changes in lipid membrane composition of abnormal erythrocytes, with increased expression of negatively charged phosphatidylserine (PS) at the outer surface, constant platelet activation due to endothelial injury, and deficiency of natural anticoagulants. Thalassemic also have chronic low-grade inflammation and impaired fibrinolysis (Angchaisuksiri et al). These changes may account for the increased risk of thrombosis in these patients. Thrombosis is largely a subclinical process in Thalassemia, with autopsies finding microvascular platelet and fibrin thrombi [11]. We postulate that this may be the reason for chronic bone infarct. Other reports of spontaneous EDH in sickle cell anemia propose a similar mechanism of bone infarct, causing periosteal elevation, disruption of cortical bone, and eventually bleeding into the extradural place. However, the causative mechanism in sickle cell anemia is vaso-occlusion, not thrombosis [12]. Another postulation of spontaneous EDH is inadequate venous drainage causing venous hypertension and venous rupture. In hematological disorders, chronic extra-medullary hematopoiesis occurs. Hyper-proliferative bone marrow disrupts the inner and outer skull margins and precipitates extravasations of blood into the subgaleal and extradural spaces. In our case, the patient's skull was found to have areas of blackish discoloration, pinpoint bleeding sites, and spongy bone, suggestive of skull infarction and hematopoietic bone (Figure 2). We hypothesize that the likely source of the EDH may be a combination of hyperproliferative bone with chronic infarcts. This theory may be confirmed with a histopathological examination of the bone. More research is required to support this hypothesis, which may not be possible due to the paucity of cases.

\section{Conclusion}

Non-traumatic spontaneous EDH should be considered in patients presenting with raised intracranial pressure symptoms, especially when significant co-morbidities are present. When diagnosed, urgent surgical decompression is indicated. The pathophysiology of EDH in haematological disorders is not well understood, and more research is required to understand this phenomenon. To our knowledge, this is the first case of spontaneous EDH associated with Beta-Thalassemia Major reported in the literature. 


\section{References}

1. Bricolo AP, Pasut LM (1984) Extradural Hematoma: Toward Zero Mortality: A Prospective Study. Neurosurgery 14(1): 8-12.

2. Groen RJM, Ponssen H (1990) The spontaneous spinal epidural hematoma: A study of the etiology. J Neurol Sci Neurological Sciences 98(23): 121-138.

3. Robertson WC, Lee YE, Edmonson MB (1979) Spontaneous spinal epidural hematoma in the young. Neurology 29(1): 120-122.

4. Mishra SS, Senapati SB, Gouda AK, Behera SK, Patnaik A (2017) Spontaneous extradural and subgaleal hematoma: A rare neurosurgical crisis of sickle cell disease. Asian J Neurosurg 12(1): 47-50.

5. Zheng FX, Chao Y (2009) Spontaneous intracranial extradural hematoma: Case report and literature review. Neurology India 57(3): 324-326.

6. Chhabra S, S Sharma, D Purohit (2017) Spontaneous extradural hematoma: a rare entity AU - Khan, Khursheed Alam. British Journal of Neurosurgery pp. 1-3.
7. Beal JC, P Overby (2012) Severe anemia leading to hypodensity of cerebral venous sinuses on computed tomography imaging. Neurohospitalist 2(1): 36-37.

8. Babu ML, Bhasin SK, Kumar A (2005) Extradural Hematoma - An Experience of 300 Cases. 7(4): 205-207.

9. Babatola BO, Salman YA, Abiola AM, Okezie KO, Oladele AS (2012) Spontaneous epidural haematoma in sickle cell anaemia: case report and literature review. J Surg Tech Case Rep 4(2): 135-137.

10. Wani AA, Ramzan AU, Kirmani AR, Bhatt AR, Hamdani N, et al. (2008) Intradiploic epidermoid causing spontaneous extradural hematoma: case report. Neurosurgery 62(4): E971.

11. Kumar A, Batra HS, Banerjee M, Bandyopadhyay S, Saha TK, et al. (2017) PAI-1 Study in Thalassemia Major Patients Receiving Multiple Blood Transfusion. Indian J Clin Biochem 32(3): 343-346.

12. Resar LM, Oliva MM, Casella JF (1996) Skull Infarction and Epidural Hematomas in a Patient with Sickle Cell Anemia. J Pediatr Hematol Oncol 18(4): 413-415.

\section{Your next submission with Juniper Publishers will reach you the below assets}

- Quality Editorial service

- Swift Peer Review

- Reprints availability

- E-prints Service

- Manuscript Podcast for convenient understanding

- Global attainment for your research

- Manuscript accessibility in different formats

( Pdf, E-pub, Full Text, Audio)

- Unceasing customer service

Track the below URL for one-step submission https://juniperpublishers.com/online-submission.php 